\title{
Assessment of heavy metal concentration in Ipomoea batatas (L.) and spinach consumed in Zanzibar by Energy Dispersive X-ray Fluorescence (EDXRF)
}

\author{
Salum $^{\text {a }}$ S.K., Suleiman ${ }^{a}$ S.A., Kimaro ${ }^{b}$ E., Chuma ${ }^{a}$ F. \\ ${ }^{a}$ Radiation Control Directorate, Tanzania Atomic Energy Commission, P.O BOX 743, Arusha, Tanzania \\ ${ }^{b}$ Ministry of Education, Science and Technology, Division of Sci, Tech \& Innovation, P.O BOX 10, Dodoma, Tanzania \\ Corresponding authore-mail: salum.salum5@taec.go.tz
}

\begin{abstract}
This work aimed to assess the levels of heavy metal concentrations in Ipomoea batatas (L.) and spinach associated with uncontrolled municipal waste, motor vehicles fumes, pesticides and fertilizer in the Urban West Region Zanzibar. Twenty samples of Ipomoea batatas (L.) and spinach were randomly collected; 15 were from farm sites, and five were from the local markets. The samples were analyzed using energy dispersive X-ray fluorescence method at Tanzania Atomic Energy Commission in Arusha. Essential and non-essential elements, namely, $\mathrm{Mn}, \mathrm{Cu}, \mathrm{Fe}, \mathrm{As}, \mathrm{Zn}, \mathrm{Pb}$ and $\mathrm{Ni}$, were detected and discussed. The samples of spinach collected from farms and local markets had significant higher $(\mathrm{P}<0.05)$ concentrations of $\mathrm{As}$, $\mathrm{Pb}$, $\mathrm{Fe}, \mathrm{Zn}$ and $\mathrm{Cu}$ than Ipomoea batatas (L.), whilst Ipomoea batatas (L.) from farms had significantly higher (P $<0.05$ ) concentrations than spinach. The mean concentration of As in samples of Ipomoea batatas (L.) from local markets was below minimum detection limit value of $0.02 \mu \mathrm{g} / \mathrm{g}$ of the EDXRF machine used in the current study. Although the mean concentration of Mn was within the range reported in the literature, the concentrations of $\mathrm{Zn}, \mathrm{Ni}, \mathrm{Cu}, \mathrm{Fe}$, $\mathrm{As}$ and $\mathrm{Pb}$ in Ipomoea batatas (L.) and spinach were recorded above the acceptable tolerance limit set by FAO/WHO for human consumption. These results suggest that both Ipomoea batatas (L.) and spinach collected from local markets and grown within the study region might expose consumers to hazardous elements.
\end{abstract}

Keywords: Heavy metals, Contamination, Ipomoea batatas (L.), Spinach, EDXRF. 


\section{INTRODUCTION}

Heavy metal contamination in vegetables cannot be underestimated, as these foodstuffs are primary components of the human diet. Vegetables are a primary important part of the human diet, as they contain protein, carbohydrate, dietary fibers, minerals and vitamins, and also have a beneficial antioxidative effect. In vegetables, biological essential and non-essential heavy metals may be present. Vegetables are contaminated when they absorb heavy metals from the soil, water and polluted air [1-4]. Studies shown that vegetables grown in soils that have accumulated high concentrations of heavy metal become contaminated $[3,5,6]$. Heavy metals can be taken up by vegetable tissues through the plants' roots and foliage and are incorporated at high levels in the edible parts of vegetables [7-9]. The application of modern technologies in agriculture, industrial activities and contamination of human food chain has contributed to the elevated levels of heavy metals in vegetables $[10,11]$. Emissions of heavy metals from the industries and vehicles may be deposited on the vegetable surfaces during production, transport and marketing. Manzoor et al. has recently reported that vegetables grown around industrial sites and near roads are exposed to higher levels of heavy metals and can pose considerable risk to the community if consumed [12]. Kibassa et al. and Hellen et al. separately reported the high concentration of heavy metals in vegetables in some regions of Tanzania, which attributed to the presence of industrial effluents and environmental pollution [13, 14].

Studies conducted in some parts of Tanzania including Zanzibar, have shown that; vegetables collected from farm sites are contaminated with heavy metals [13-15]. Najat et al. analyzed vegetables from Dimani, Chukwani, Mwera and Migombani in Zanzibar that were cultivated along the main road [16]. A previous study [13] also reported the data from samples collected close to the main road and in proximity of the river valley. In both cited studies, reported concentrations of $\mathrm{Pb}, \mathrm{Ni}$ and $\mathrm{Cr}$ exceeded the permissible limit set by $\mathrm{FAO} / \mathrm{WHO}$. Frequently consuming such vegetables may result in serious health problems. For instance, heavy metals such as $\mathrm{Zn}, \mathrm{Cu}, \mathrm{Mn}$ and Fe are considered essential components for biochemical reactions in the bod; however, they can reportedly affect human metabolism at high concentration $[17,18] \mathrm{Hg}, \mathrm{Pb}, \mathrm{Cd}, \mathrm{Ni}$ and $\mathrm{As}$ are toxic and are regarded as biologically 
nonessential [19, 20]. These toxic elements could reach the human body through various absorption pathways, such as ingestion, dermal contact, diet using a soil-food chain, oral intake, and inhalation, and cause various diseases or disorders [3, 21, 22]. Furthermore, due to the persistent nature and cumulative behavior of heavy metals, they can enter food chains and cause toxic effects on humans' health [23]. Various studies have also reported that toxic elements in the human body can cause mental and central nervous system damage [23-25]. Hence, frequent assessment of heavy metals concentration in vegetables is needed to ensure that their levels meet the international standards for the safety of consumers. The present study was conducted to assess the heavy metals concentrations of $\mathrm{Mn}, \mathrm{Cu}, \mathrm{Fe}, \mathrm{As}, \mathrm{Zn}, \mathrm{Pb}$ and $\mathrm{Ni}$ in Ipomoea batatas (L.) (IB) and spinach (SP) consumed in Zanzibar. Samples were collected randomly from the local markets and production site (farms) near the roadside in Urban West Region, Zanzibar and analyzed with Energy Dispersive X-ray Fluorescence Spectroscopy (EDXRF).

\section{MATERIALS AND METHODS}

\subsection{Study area and samples collection}

This study was conducted in Unguja Urban West Region, Zanzibar with a population of about 593,678 (46\%) [26]. In this region, the small-scale farms of vegetables, such as IB and SP are cultivated in open space, between settlements and very close to roads. Both samples of IB and SP were collected from polluted agricultural soil. Vegetables grown in these locations are at high risk of exposure to heavy metals due to rapid industrialization, uncontrolled municipal waste and motor vehicle fumes. Twenty samples of IB and SP were randomly collected; fifteen were from farm sites, and five were from the local markets in the Urban West Region, Zanzibar. The local markets were Mombasa, Darajani, Mikunguni and Mwanakwerekwe, whereas farm sites were Kijichi, Maungani, Mwera, Kwarara, Buyu, Fuoni, Migombani, Chukwani, Melinne, Maruhubi and Mbweni (Figure 1). All samples were collected in clean labelled polythene bags and brought to Tanzania Atomic Energy Commission laboratory at Arusha for preparation and analysis. 

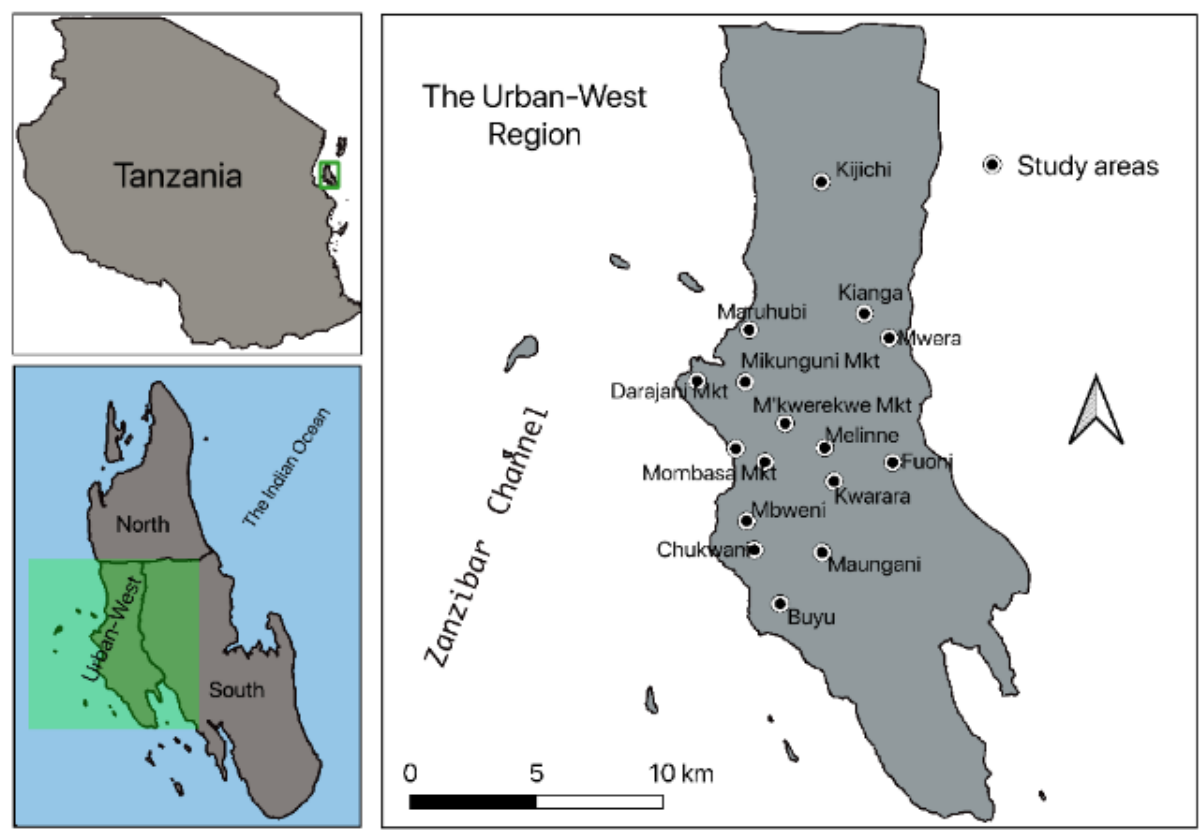

Figure 1. Map of Urban-West Region, Zanzibar showing the sampling points.

\subsection{Preparation and treatment of samples}

The collected samples were thoroughly washed with distilled water to remove any traces of elements resulting from contaminations. Then, the samples were cut into small pieces, air-dried, and placed in an electric oven at $60{ }^{\circ} \mathrm{C}$ to remove moisture. After drying, the samples were grounded using an electric grinder to achieve a very fine powder (size $<0.074 \mathrm{~mm}$ ), which was then sieved and stored in well-labelled plastic bags for analysis.

\subsection{XRF sample preparation}

A dry weight of $4 \mathrm{~g}$ of each sieved sample was weighed into $0.9 \mathrm{~g}$ of starch binder using an electronic balance. The resulting mixture was placed into a bowl together with four spherical balls and affixed to a pulverizer for further milling and homogenization. The pulveriser machine was set at a speed of $150 \mathrm{rev} / \mathrm{min}$ for $15 \mathrm{~min}$. Each pulverized sample was manually pressed into pallets using the hydraulic Retsch ${ }^{\mathrm{TM}}$ Retsch GmbH Retsch-Allee. The pellets were placed in the Spectro Xepos ${ }^{\mathrm{TM}}$ EDXRF machine for measurement and analysis. 


\subsection{Determination of elemental composition}

The elemental analysis of pulverized samples were determined using energy dispersive Xray spectrometer. The machine was operated by automated turbo-quant X-lab ProTM software at a rate of $50 \mathrm{~W}$ and $50 \mathrm{Kv}$. The florescence was collected by a $\mathrm{Si}(\mathrm{Li})$ detector with a resolution $(\mathrm{FWHM})$ of $\mathrm{MnK} \alpha \leq 160 \mathrm{eV}$. A spectrum run for $15 \mathrm{~min}$ gave good continuity statistics and resolution of the peaks. The concentrations of individual elements were determined by using fundamental parameter method inbuilt in X-lab Pro computer software, in which matrix effects were counted for.

\subsection{Statistical analysais}

One-way ANOVA was used to evaluate the differences among vegetables species. Prior to ANOVA, the homogeneities of the variances were verified using Levene's test. A t-test was used to statistically compare the mean concentrations of elements collected from the two groups (farm site and local market). A probability level of $\mathrm{p}<0.05$ was considered statistically significant. All data were presented as arithmetic mean with standard deviation attached. All statistical analyses were made using the software Excel 2013 and SPSS Version 23, and figures were produced using Origin Version 8.5 software.

\section{RESULTS AND DISCUSSION}

\subsection{Ipomoea batatas (L.) from markets and farm sites}

Concentrations $(\mu \mathrm{g} / \mathrm{g})$ of $\mathrm{Mn}, \mathrm{Zn}, \mathrm{Ni}, \mathrm{Cu}, \mathrm{Fe}, \mathrm{As}$ and $\mathrm{Pb}$ in samples of $\mathrm{IB}$ collected randomly from local markets and farm sites at Unguja Urban West Region, Zanzibar were determined. The t-test was used to statistically compare the mean concentrations of elements collected in samples from farm sites and local markets. In this test, the significant value was $\mathrm{p}<$ 0.05 . The concentrations of heavy metals in these samples varied as shown in Table 1. 
Table 1. Mean concentrations $(\mu \mathrm{g} / \mathrm{g}$ ) of selected elements detected in Ipomoea batatas (L.) samples collected from farms and markets.

\begin{tabular}{ccc}
\hline Elements & Farms & Markets \\
\hline $\mathrm{Mn}$ & $117.03 \pm 5.02(84.05-160.30)$ & $90.96 \pm 6.28(83.91-100.79)$ \\
$\mathrm{Zn}$ & $26.67 \pm 0.73(17.63-36.04)$ & $21.69 \pm 0.99(17.63-25.10)$ \\
$\mathrm{Ni}$ & $2.06 \pm 0.30(0.64-11.56)$ & $0.83 \pm 0.22(0.6-1.01)$ \\
$\mathrm{Cu}$ & $20.00 \pm 0.94(8.41-57.75)$ & $11.51 \pm 0.92(6.27-16.19)$ \\
$\mathrm{Fe}$ & $1409.58 \pm 52.86(741.96-2344.73)$ & $969.24 \pm 53.70(679.51-1544.05)$ \\
$\mathrm{As}$ & $0.47 \pm 0.09(0.39-0.54)$ & MDL \\
$\mathrm{Pb}$ & $3.55 \pm 0.45(1.57-6.08)$ & $2.60 \pm 0.33(1.03-3.80)$ \\
\hline
\end{tabular}

The samples from farm sites had significantly $(\mathrm{p}<0.05)$ higher concentration values of $\mathrm{Mn}$, $\mathrm{Zn}, \mathrm{Ni}, \mathrm{Cu}, \mathrm{Fe}, \mathrm{As}$ and $\mathrm{Pb}$. However, the mean concentration of As from local markets was below minimum detection limit value of $0.02 \mu \mathrm{g} / \mathrm{g}$ according to the measurement of the EDXRF machine used in the current study; therefore, it was not detected. The mean concentration of $\mathrm{Pb}$ was much higher in the samples from farms compared with those from local markets (Figure 2). Moreover, the levels of $\mathrm{Pb}$ in samples of IB collected from local markets and farms were about 12 and 9 times higher than $0.3 \mu \mathrm{g} / \mathrm{g}$, which was the acceptable tolerance level (ATL) set by FAO/WHO [27]. The high concentration of $\mathrm{Pb}$ in samples of vegetables analyzed in the present study was associated with roadside locations of the majority of the farms, where the vegetables were exposed to a high amount of $\mathrm{Pb}$ from vehicular traffic. High levels of $\mathrm{Pb}$ in samples of $\mathrm{IB}$ were also reported by Kihampa et al. [28]. In his study, the samples of IB were collected from in the vicinity of a closed dumpsite, whereas in this study, the samples were collected near the main road. 


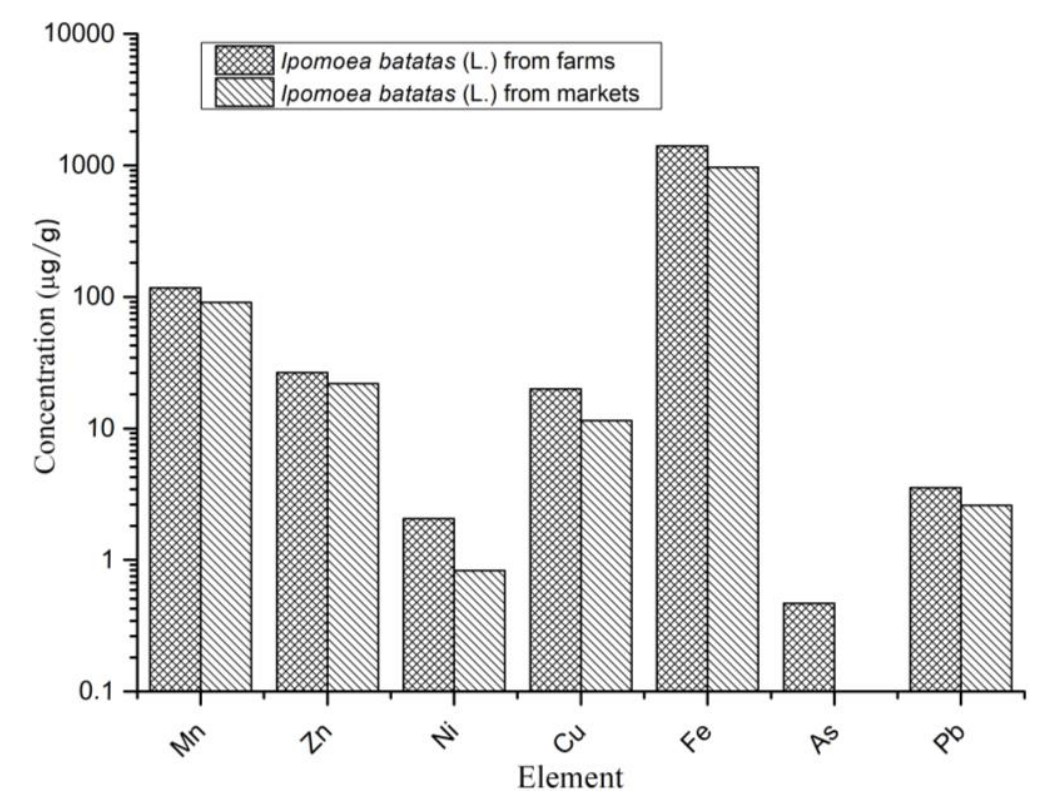

Figure 2: Comparison of elements concentrations in Ipomoea batatas (L.) from farms and local markets.

In this study, the mean concentrations of $\mathrm{Cu}$ in samples of IB in both groups were much lower than $62.12 \mu \mathrm{g} / \mathrm{g}$, which was the $\mathrm{Cu}$ concentration reported in IB sample by Wiberforce et al. in 2013 [29]. Our result was nearly in agreement with the findings of Kihampa et al., who reported the $22.47 \mu \mathrm{g} / \mathrm{g}$ concentration of $\mathrm{Cu}$ in the sample of IB [28]. However, the $20 \mu \mathrm{g} / \mathrm{g}$ and $11.51 \mu \mathrm{g} / \mathrm{g}$ concentrations of $\mathrm{Cu}$ are 4 and 2 times higher, respectively, than $5 \mu \mathrm{g} / \mathrm{g}$ ATL set by FAO/WHO [27]. Zn contents in a sample of IB from farms and local markets were approximately 5 and 4 times higher, respectively, than $5 \mu \mathrm{g} / \mathrm{g}$ value as ATL set by FAO/WHO [27]. These findings were due to fact that the farm sites reportedly used chicken manure on vegetable crops. The application of this manure to vegetable crops resulted in the accumulation of high of $\mathrm{Zn}[30]$.

The amounts of $\mathrm{Fe}, \mathrm{Mn}, \mathrm{Ni}$ and As in the samples collected from farm sites were also higher than those collected from the market. The reasonable explanation of this situation is that most samples collected from the markets originated from villages that were exposed to low amounts of $\mathrm{Fe}, \mathrm{Mn}, \mathrm{Ni}$ and As from road traffic and industrial activities. The mean concentrations of Fe in IB from the farms and local markets were 1409.58 and $969.24 \mu \mathrm{g} / \mathrm{g}$, respectively, which were 7 and 5 times higher than the ATL of 214 set by WHO/FAO [27]. The high Fe concentrations 
were due to, the fact that Fe uptake was promoted, and Fe accumulated in the leaf, which is the food-producing organ of a plant. The amount of Fe contents in the samples might be originated from the use of pesticides and fertilizer.

The mean concentrations of $\mathrm{Mn}$ in IB from both groups of samples were approximately 117.03 and $90.96 \mu \mathrm{g} / \mathrm{g}$, respectively, which were 9 and 11 times lower than the ATL of 1000 $\mu \mathrm{g} / \mathrm{g}$ set by WHO/FAO [27]. The mean $\mathrm{Ni}$ concentrations were 2.06 and $0.83 \mu \mathrm{g} / \mathrm{g}$ in the samples of from farms and markets, respectively, which were 10 and 4 times higher than the ATL of $0.3 \mu \mathrm{g} / \mathrm{g}$ set by WHO/FAO [27]. The high concentration of Ni from farm samples was due to the reported use of phosphate fertilisers known as boosters, which contain high amounts of heavy metals, such as $\mathrm{Ni}$ [31]. Therefore, long-term accumulation of heavy metals in the soil might have caused accumulation in the vegetables via root uptake. Conversely, As was only found in the farm samples at mean concentrations of approximately 9 times higher than the ATL of $0.05 \mu \mathrm{g} / \mathrm{g}$ set by WHO/FAO [27]. The higher levels of As obtained in the farm samples could be attributed to the release of the metals or its compounds from the small-scale industries situated in the area.

\subsection{Spinach from markets and farms}

The heavy metals mean concentrations values $(\mu \mathrm{g} / \mathrm{g})$ in spinach collected randomly from farm sites and local markets at Unguja Urban West Region, Zanzibar were obtained. The detection levels of heavy metals were in the following order: $\mathrm{Fe}>\mathrm{Mn}>\mathrm{Zn}>\mathrm{Cu}>\mathrm{Pb}>\mathrm{Ni}>$ As. The levels were in the following range for the samples from farms: $2270.74-3163.52 \mu \mathrm{g} / \mathrm{g}$ for $\mathrm{Fe}$; 75.14-131.09 $\mu \mathrm{g} / \mathrm{g}$ for $\mathrm{Mn} ; 38.22-52.81 \mu \mathrm{g} / \mathrm{g}$ for $\mathrm{Zn}$; $19.18-128.80 \mu \mathrm{g} / \mathrm{g}$ for $\mathrm{Cu}$; 2.92-4.48 $\mu \mathrm{g} / \mathrm{g}$ for $\mathrm{Pb} ; 0.97-2.48 \mu \mathrm{g} / \mathrm{g}$ for $\mathrm{Ni}$; and $0.39-1.29 \mu \mathrm{g} / \mathrm{g}$ for As. The levels were in the following ranges for the samples from local markets: $3515.22-5400.54 \mu \mathrm{g} / \mathrm{g}$ for Fe; 131.09-148.53 $\mu \mathrm{g} / \mathrm{g}$ for $\mathrm{Mn} ; 1.90-4.74 \mu \mathrm{g} / \mathrm{g}$ for $\mathrm{Zn} ; 20.73-25.30 \mu \mathrm{g} / \mathrm{g}$ for $\mathrm{Cu} ; 3.85-5.95 \mu \mathrm{g} / \mathrm{g}$ for $\mathrm{Pb}$; $0.6-1.01 \mu \mathrm{g} / \mathrm{g}$ for $\mathrm{Ni}$; and $1.21-2.13 \mu \mathrm{g} / \mathrm{g}$ for As, as shown in Table 2. 
Table 2: Mean concentrations $(\mu \mathrm{g} / \mathrm{g})$ of selected elements detected in spinach samples collected from farms and markets.

\begin{tabular}{ccc}
\hline Elements & Farms & Markets \\
\hline $\mathrm{Mn}$ & $99.74 \pm 6.66(75.14-131.09)$ & $139.81 \pm 7.81(131.09-148.53)$ \\
$\mathrm{Zn}$ & $43.82 \pm 0.77(38.22-52.81)$ & $45.605 \pm 1.41(1.90-4.74)$ \\
$\mathrm{Ni}$ & $1.67 \pm 0.26(0.97-2.48)$ & $3.32 \pm 0.37(0.6-1.01)$ \\
$\mathrm{Cu}$ & $55.75 \pm 1.66(19.18-128.80)$ & $23.02 \pm 1.31(20.73-25.30)$ \\
$\mathrm{Fe}$ & $2607.8 \pm 45.12(2270.74-3163.52)$ & $4457.88 \pm 132.65(3515.22-5400.54)$ \\
$\mathrm{As}$ & $0.74 \pm 0.24(0.39-1.29)$ & $1.67 \pm 0.38(1.21-2.13)$ \\
$\mathrm{Pb}$ & $4.82 \pm 0.41(2.92-4.48)$ & $4.9 \pm 0.45(3.85-5.95)$ \\
\hline
\end{tabular}

Among the metals examined, Fe had the highest mean concentrations, whereas As had the lowest mean concentrations. This finding was due to the fact that Fe uptake was promoted, and Fe accumulated in the leaf, which is the food-producing organ of a plant. Figure 3 provides a comparison of selected heavy metals in SP collected randomly from farms and local markets at Unguja Urban West Region, Zanzibar. The t-test shows that samples from farms had significantly higher $(\mathrm{p}<0.05) \mathrm{Cu}$ concentration values, whereas samples from the markets had significantly high concentrations of $\mathrm{Mn}, \mathrm{Zn}, \mathrm{Ni}, \mathrm{Fe}, \mathrm{As}$ and $\mathrm{Pb}$. The mean concentration values of $\mathrm{Fe}, \mathrm{As}, \mathrm{Ni}$ and $\mathrm{Mn}$ in samples of SP collected from Mwanakwerekwe market were much higher than those in samples from other locations. According to Uwah et al. the elevated mean concentrations of Fe in SP could be attributed to the constant application of fertilizer and other agro-chemicals [32]. 


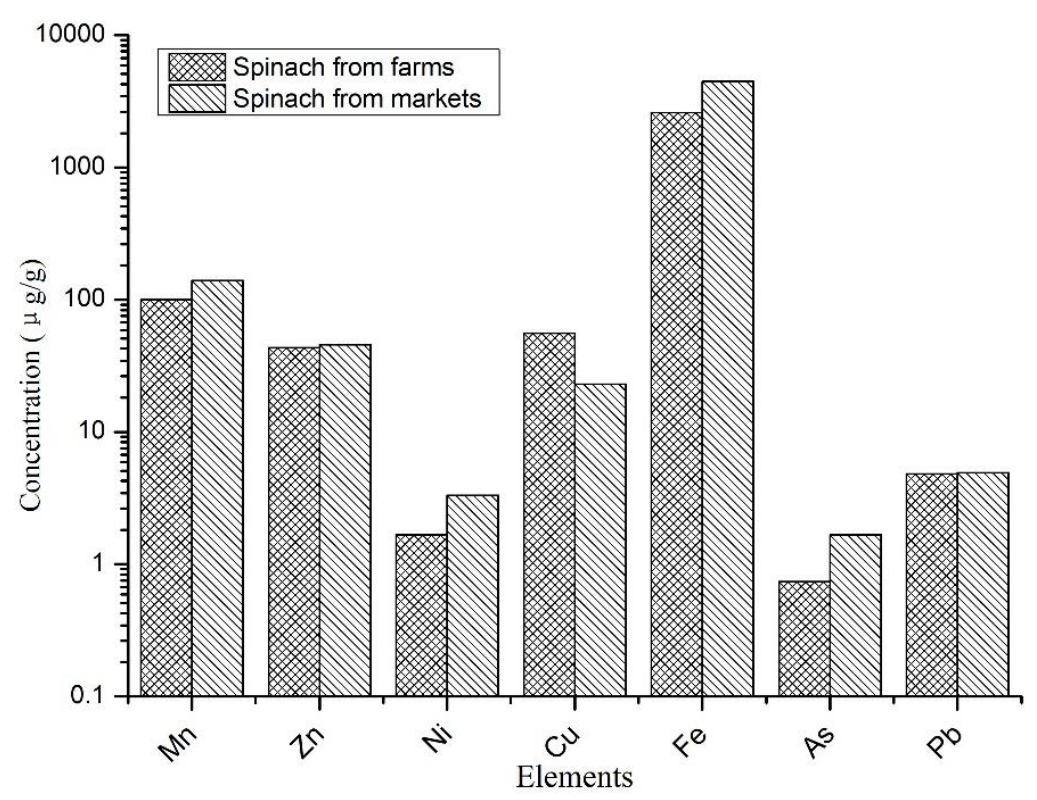

Figure 3: Comparison of element concentrations in spinach from farms and local markets.

\subsection{Spinach and Ipomoea batatas (L.) from farms}

The comparative plot in Figure 4 shows the mean concentrations of selected elements in IB in contrast to those in SP. The t-test showed that samples of SP had significantly $(p<0.05)$ higher concentrations of $\mathrm{As}, \mathrm{Pb}, \mathrm{Zn}$ and $\mathrm{Cu}$ than samples of IB. In samples of SP, the mean concentration of Fe and $\mathrm{Zn}$ were $2607.8 \pm 45.12 \mu \mathrm{g} / \mathrm{g}$ and $43.82 \pm 0.77 \mu \mathrm{g} / \mathrm{g}$, which were 1.9 times and 1.6 times higher, respectively, than the mean concentrations in sample of IB, making $\mathrm{SP}$ more nutritious than IB. The difference in the concentrations of $\mathrm{Pb}, \mathrm{Ni}$ and $\mathrm{As}$ was not statistically significant between IB and SP, although the highest mean concentrations of $\mathrm{Pb}$ and As were found in SP samples. 


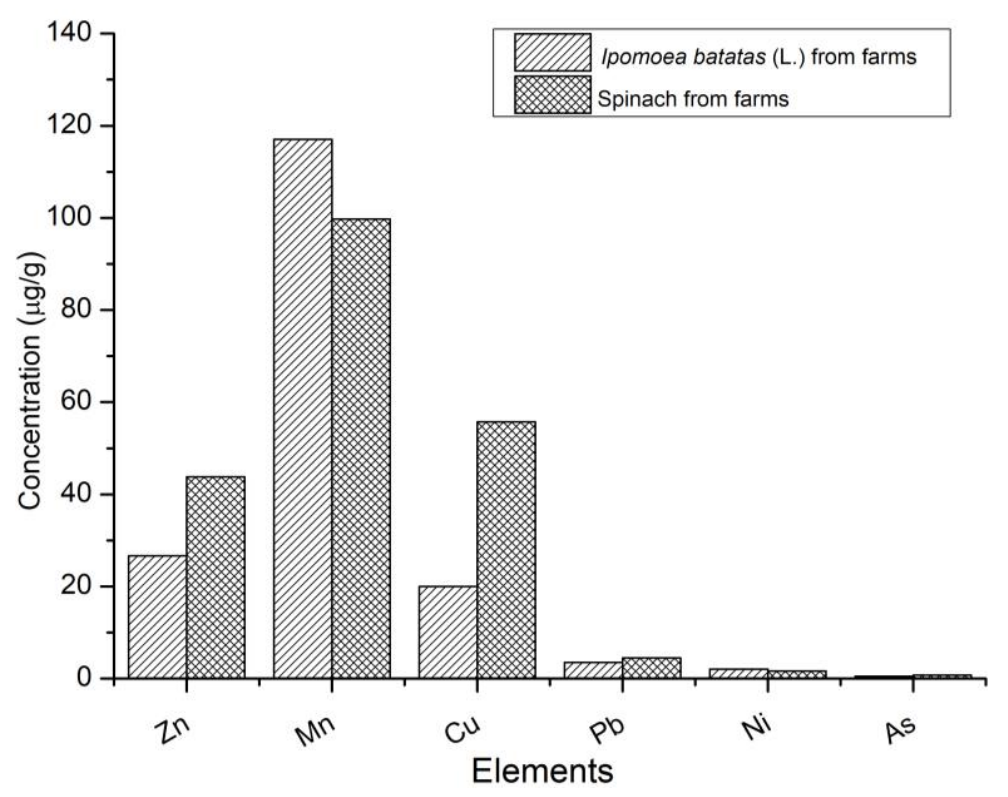

Figure 4: The histogram showing the concentration of selected elements in Ipomoea batatas (L.) and spinach collected from the farms.

\subsection{Spinach and Ipomoea batatas (L.) from local markets}

Figure 5 shows a comparison of the mean concentration values of selected elements from samples of SP and IB collected from local markets. The t-test result showed that SP samples had significantly higher $(\mathrm{p}<0.05)$ concentration values of $\mathrm{Zn}, \mathrm{Mn}, \mathrm{Cu}, \mathrm{Pb}, \mathrm{Ni}, \mathrm{Fe}$ and $\mathrm{As}$ than samples of IB. The mean concentration values of $\mathrm{Zn}, \mathrm{Mn}, \mathrm{Cu}, \mathrm{Pb}, \mathrm{Ni}$ and $\mathrm{As}$ in SP were about 2.1, 1.5, 2, 1.9, 4 and 1.7 times higher than those in sample of IB. The high mean concentration values of these elements were detected in SP samples from Mwanakwerekwe market than in SP samples from any other local markets. This result was due to the fact that the samples collected from Mwanakwerekwe market were reportedly imported from Dar-es-Salaam and other regions outside Zanzibar. Therefore, the consumption of SP from local markets, particularly SP from Mwanakwerekwe market, exposes the Zanzibar consumers to toxic elements more than the consumption of IB. 


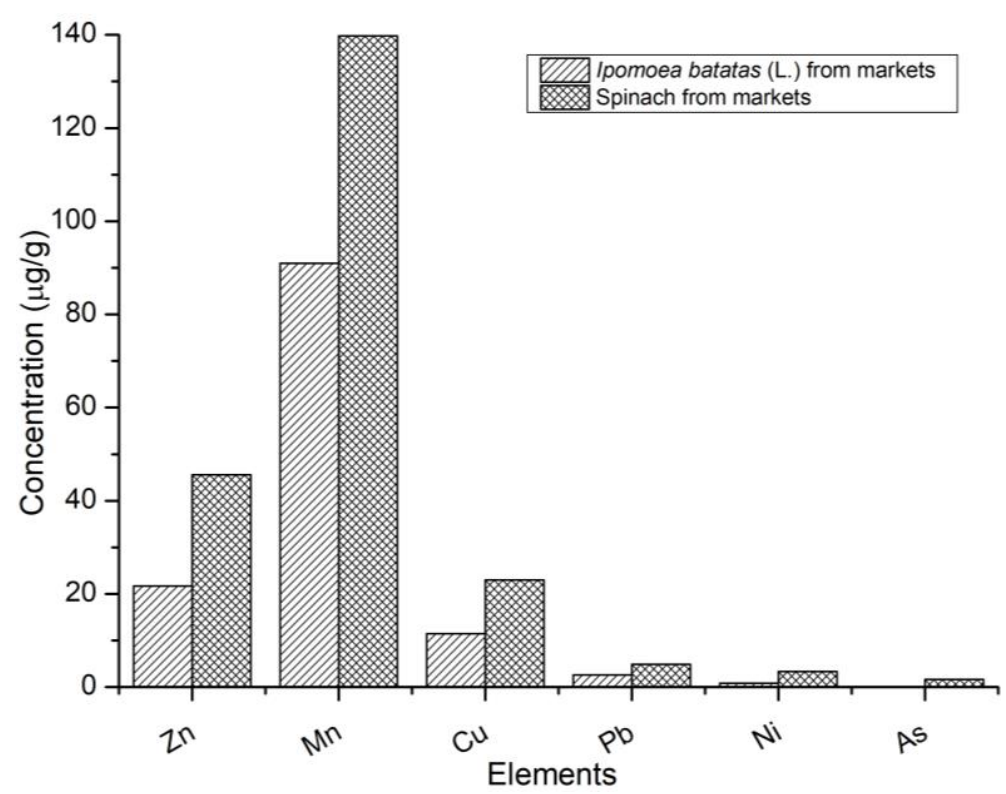

Figure 5: A histogram showing the concentrations of selected elements in Ipomoea batatas (L.) and spinach collected from the market.

\section{CONCLUSION}

This study was conducted to assess the concentrations of $\mathrm{Mn}, \mathrm{Cu}, \mathrm{Fe}, \mathrm{As}, \mathrm{Zn}, \mathrm{Pb}$ and $\mathrm{Ni}$ in IB and SP from farm sites and local markets by using EDXRF nuclear technique. The results reported in the current study show that the mean concentrations of $\mathrm{Zn}, \mathrm{Ni}, \mathrm{Cu}, \mathrm{Fe}, \mathrm{As}$ and $\mathrm{Pb}$ in IB and SP from farm sites and local markets were above the ATL set by FAO/WHO [27]. The results also indicate that the mean concentration of As in samples of IB from local markets was below the minimum detection limit value of $0.02 \mu \mathrm{g} / \mathrm{g}$ according to measurements made using EDXRF machine. The mean concentration values of $\mathrm{Pb}$ in IB collected from local markets and farm sites were about 12 and 9 times higher than $0.3 \mu \mathrm{g} / \mathrm{g}$ ATL set by FAO/WHO, respectively [27]. This finding was due to the fact that most farm sites were situated near the road, and thus, the IBs were exposed to get high amounts of $\mathrm{Pb}$ from vehicular traffic. Similarly, the mean concentration values of $\mathrm{Zn}$ in the sample of IB were about 5 times higher than the $5 \mu \mathrm{g} / \mathrm{g}$ ATL set by FAO/WHO [27]. The high concentration values of $\mathrm{Zn}$ in the IB samples were associated with the application of chicken manure in the production of vegetable crops. The application of chicken manure in vegetable crops was revealed to contain high contents of $\mathrm{Zn}$ [30]. 
The t-test indicated that SP samples had significantly $(\mathrm{p}<0.05)$ higher mean concentrations of $\mathrm{As}, \mathrm{Pb}, \mathrm{Ni}, \mathrm{Zn}$ and $\mathrm{Cu}$ than samples of IB samples collected from farm sites. The concentration values of $\mathrm{Pb}$ and $\mathrm{As}$ were 1.9 and 1.7 times higher, respectively, in samples of IB collected from farm sites than those collected from markets. SP samples from Mwanakwerekwe market showed a higher concentration values of these elements than those from any other local market. This finding was due to the fact that SP samples collected from Mwanakwerekwe market were reportedly imported from Dar-es-Salaam, region with have higher concentration values of toxic elements due to the presence of large number of industries and municipal waste. The findings also show that the SP samples collected from local markets particularly at Mwanakwerekwe market were more contaminated with $\mathrm{As}, \mathrm{Pb}$ and $\mathrm{Ni}$ compared with $\mathrm{IB}$ samples. General the results suggest that the consumption of SP and IB collected from local markets and those grown within the study area might expose consumers to hazardous elements especially in Urban West Region, Zanzibar.

\section{ACKNOWLEDGMENT}

This research was financially supported by the Tanzania Atomic Energy Commission (TAEC). The Authors acknowledge and express their gratitude for TAEC's support in terms of the provision of necessary laboratory facilities and technical support.

\section{REFERENCES}

[1] SINGH, A.; SHARMA, R. K.; AGRAWAL, M.; MARSHALL, F. M. Risk assessment of heavy metal toxicity through contaminated vegetables from waste water irrigated area of Varanasi, India. Tropical ecology, v. 51, p.375-387, 2010.

[2] LUO, C.; LIU, C.; WANG, Y.; LIU, X.; LI, F.; ZHANG, G.; LI, X. Heavy metal contamination in soils and vegetables near an e-waste processing site, south China. Journal of hazardous materials, v. 186, p.481-490, 2011. 
[3] TAGHIPOUR, H.; MOSAFERI, M. Heavy metals in the vegetables collected from production sites. Health promotion perspectives, v. 3, p.185-193, 2013.

[4] CHANG, C. Y.; YU, H. Y.; CHEN, J. J.; LI, F. B.; ZHANG, H. H.; LIU, C. P. Accumulation of heavy metals in leaf vegetables from agricultural soils and associated potential health risks in the Pearl River Delta, South China. Environmental monitoring and assessment, v. 186, p.1547-1560, 2014.

[5] AHMAD, J. U.; GONI, M. A. Heavy metal contamination in water, soil, and vegetables of the industrial areas in Dhaka, Bangladesh. Environmental monitoring and assessment, v. 166, p. 347-357, 2010.

[6] ZHOU, H.; YANG, W.T.; ZHOU, X.; LIU, L.; GU, J. F.; WANG, W. L.; ZOU, J. L.; TIAN, T.; PENG, P. Q.; LIAO, B. H. Accumulation of heavy metals in vegetable species planted in contaminated soils and the health risk assessment. International journal of environmental research and public health, v. 13, p. 289, 2016.

[7] NWAJEI, G. E. Trace elements in soils and vegetations in the vicinity of shell Petroleum Development Company operating area in Ughelli, delta state of Nigeria. American Eurasian. Journal of Sustainable Agriculture, v. 3, p. 574-578, 2009.

[8] YANG, Y.; ZHANG, F. S.; LI, H. F.; JIANG, R. F. Accumulation of cadmium in the edible parts of six vegetable species grown in Cd-contaminated soils. Journal of environmental management, v. 90, p. 1117-1122, 2009.

[9] JOLLY, Y.N.; ISLAM, A.; AKBAR, S. Transfer of metals from soil to vegetables and possible health risk assessment. Springer Plus, v. 2, p. 385, 2013.

[10] HAMILTON, A. J.; BURRY, K.; MOK, H. F.; BARKER, S. F.; GROVE, J. R.; WILLIAMSON, V. G. Give peas a chance? Urban agriculture in developing countries. A review. Agronomy for sustainable development, v. 34, p. 45-73, 2014.

[11] ONAKPA, M. M.; NJAN, A. A.; KALU, O. C. A review of heavy metal contamination of food crops in Nigeria. Annals of global health, v. 84, p. 488-494, 2018. 
[12] MANZOOR, J.; SHARMA, M.; WANI, K. A. Heavy metals in vegetables and their impact on the nutrient quality of vegetables: A review. Journal of Plant Nutrition, v. 41, p. 1744-1763, 2018.

[13] KIBASSA, D.; KIMARO, A.A.; SHEMDOE, R. S. Heavy metals concentrations in selected areas used for urban agriculture in Dar es Salaam, Tanzania. Scientific Research and Essays, v. 8, p. 1296-1303, 2013.

[14] HELLEN, L. E.; OTHMAN, O. C. Heavy Metal Levels in Soil, Tomatoes and Selected Vegetables from Morogoro Region, Tanzania. International Journal of Environmental Monitoring and Analysis, v. 4, p. 82-88, 2016.

[15] KACHOLI, D.S.; SAHU, M. Levels and health risk assessment of heavy metals in soil, water, and vegetables of Dar es Salaam, Tanzania. Journal of Chemistry, v. 2018, p. 9, 2018.

[16] NAJAT K, M.; FATMA, O. K. Assessment of heavy metal contamination in vegetables consumed in Zanzibars. Natural Science, v. 4, p. 588-594, 2012.

[17] TCHOUNWOU, P. B.; YEDJOU, C. G.; PATlOLlA, A. K.; SUTTON, D. J. Heavy metal toxicity and the environment. In Molecular, clinical and environmental toxicology. Springer, Basel, v. 101, p. 133-164, 2012.

[18] ANDRESEN, E.; PEITER, E.; KÜPPER, H. Trace metal metabolism in plants. Journal of Experimental Botany, v. 69, p. 909-954, 2018.

[19] ATOBATELE, O. E.; OLUTONA, G. O. Distribution of three non-essential trace metals (Cadmium, Mercury and Lead) in the organs of fish from Aiba Reservoir, Iwo, Nigeria. Toxicology reports, v. 2, p. 896-903, 2015.

[20] BARONE, G.; DAMBROSIO, A.; STORELli, A.; GAROFALO, R.; BUSCO, V. P.; STORELLI, M. M. Estimated dietary intake of trace metals from swordfish consumption: a human health problem. Toxics, v. 6, p. 22, 2018. 
[21] XIE, W.; PENG, C.; WANG, H.; CHEN, W. Health risk assessment of trace metals in various environmental media, crops and human hair from a mining affected area. International journal of environmental research and public health, v. 14, p.1595, 2017.

[22] ANTONIADIS, V.; SHAHEEN, S. M.; LEVIZOU, E.; SHAHID, M.; NIAZI, N. K.; VITHANAGE, M.; OK, Y.S.; BOLAN, N.; RINKLEBE, J. A critical prospective analysis of the potential toxicity of trace element regulation limits in soils worldwide: Are they protective concerning health risk assessment?-A review. Environment international, v. 127, p. 819-847, 2019.

[23] SHARMA, R. K.; AGRAWAL, M.; MARSHALL, F. M. Heavy metals in vegetables collected from production and market sites of a tropical urban area of India. Food and chemical toxicology, v. 47, p. 583-591, 2009.

[24] CHEN, Y.; WU, P.; SHAO, Y.; YING, Y. Health risk assessment of heavy metals in vegetables grown around battery production area. Scientia agricola, v. 71, p. 126-132, 2014.

[25] JAISHANKAR, M.; TSETEN, T.; ANBALAGAN, N.; MATHEW, B. B; BEEREGOWDA, K. N. Toxicity, mechanism and health effects of some heavy metals. Interdisciplinary toxicology, v. 7, p.60-72, 2014.

[26] NATIONAL BUREAU OF STATISTICS. Tanzania-Population and Housing Census, 2012. Available at: <https://www.nbs.go.tz/index.php/en/census-surveys/population-andhousing-census>. Last accessed: 20 February. 2021.

[27] FAO/WHO. Food additives and contaminants, Joint Codex Alimentarius Commission, FAO/WHO. Food standards Programme, ALINORM 01/12A, 2001.

[28] KIHAMPA, C.; MWEGOHA, W. J.; SHEMDOE, R. S. Heavy metals concentrations in vegetables grown in the vicinity of the closed dumpsite. International journal of environmental sciences, v. 2, p. 889-895, 2011. 
[29] WILBERFORCE, J. O.; NWABUE, F. I. Uptake of heavy metals by Dioscorea rotundata (white yam) and Ipomoea batatas (sweet potato) from enyigba lead-zinc derelict. Environment and Pollution, v. 2, p. 79-84, 2013.

[30] WONG, K. W.; YAP, C. K.; NULIT, R.; OMAR, H.; ARIS, A. Z.; CHENG, W. H.; LATIF, M. T; LEOW, C.S. Zn in vegetables: A review and some insights. Integr Food Nutr Metab, v. 6, p. 1-7, 2019.

[31] MODAIHSH, A.S.; AL-SWAILEM, M.S.; MAHJOUB, M.D. Heavy metal content of commercial inorganic fertilzer used in the Kingdom of Saudi Arabia. Agricultural and Marine Sciences, v. 9, p. 21-25, 2004.

[32] UWAH, E. I.; NDAHI, N. P.; ABDULRAHMAN, F. I.; OGUGBUAJA, V. O. Heavy metal levels in spinach (Amaranthus caudatus) and lettuce (Lactuce sativa). Journal of Environmental Chemistry and Ecotoxicology, v. 3, p. 264-271, 2011. 